\title{
Wireless Substitution: Early Release of Estimates From the National Health Interview Survey, July-December 2009
}

\author{
by Stephen J. Blumberg, Ph.D., and Julian V. Luke \\ Division of Health Interview Statistics, National Center for Health Statistics
}

\section{Overview}

Preliminary results from the JulyDecember 2009 National Health Interview Survey (NHIS) indicate that the number of American homes with only wireless telephones continues to grow. One of every four American homes $(24.5 \%)$ had only wireless telephones (also known as cellular telephones, cell phones, or mobile phones) during the last half of 2009an increase of 1.8 percentage points since the first half of 2009. In addition, one of every seven American homes (14.9\%) had a landline yet received all or almost all calls on wireless telephones. This report presents the most up-to-date estimates available from the federal government concerning the size and characteristics of these populations.

\section{NHIS Early Release Program}

This report is published as part of the NHIS Early Release Program. In May and December of each year, the Centers for Disease Control and Prevention's National Center for Health Statistics (NCHS) releases selected estimates of telephone coverage for the civilian noninstitutionalized U.S. population based on data from NHIS, along with comparable estimates from NHIS for the previous 3 years. The estimates are based on in-person interviews that NHIS conducts continuously throughout the year to collect information on health status, health-related behaviors, and health care utilization. The survey also includes information about household telephones and whether anyone in the household has a wireless telephone.

Two additional reports are published as part of the NHIS Early
Release Program. Early Release of Selected Estimates Based on Data From the National Health Interview Survey is published quarterly and provides estimates for 15 selected measures of health. Health Insurance Coverage: Early Release of Estimates From the National Health Interview Survey is also published quarterly and provides additional estimates regarding health insurance coverage.

\section{Methods}

For many years, NHIS has included questions on residential telephone numbers, to permit recontacting of survey participants. Starting in 2003, additional questions were asked to determine whether a family's telephone number reached a landline telephone. Respondents were also asked whether "you or anyone in your family has a working cellular telephone.”

A “family" can be an individual or a group of two or more related persons living together in the same housing unit (a "household"). Thus, a family can consist of only one person, and more than one family can live in a household (including, for example, a household where there are multiple single-person families, as when unrelated roommates are living together).

In this report, families are identified as "wireless families" if anyone in the family had a working cellular telephone at the time of interview. This person (or persons) could be a civilian adult, a member of the military, or a child. Households are identified as "wireless-only" if they include at least one wireless family and if there are no working landline

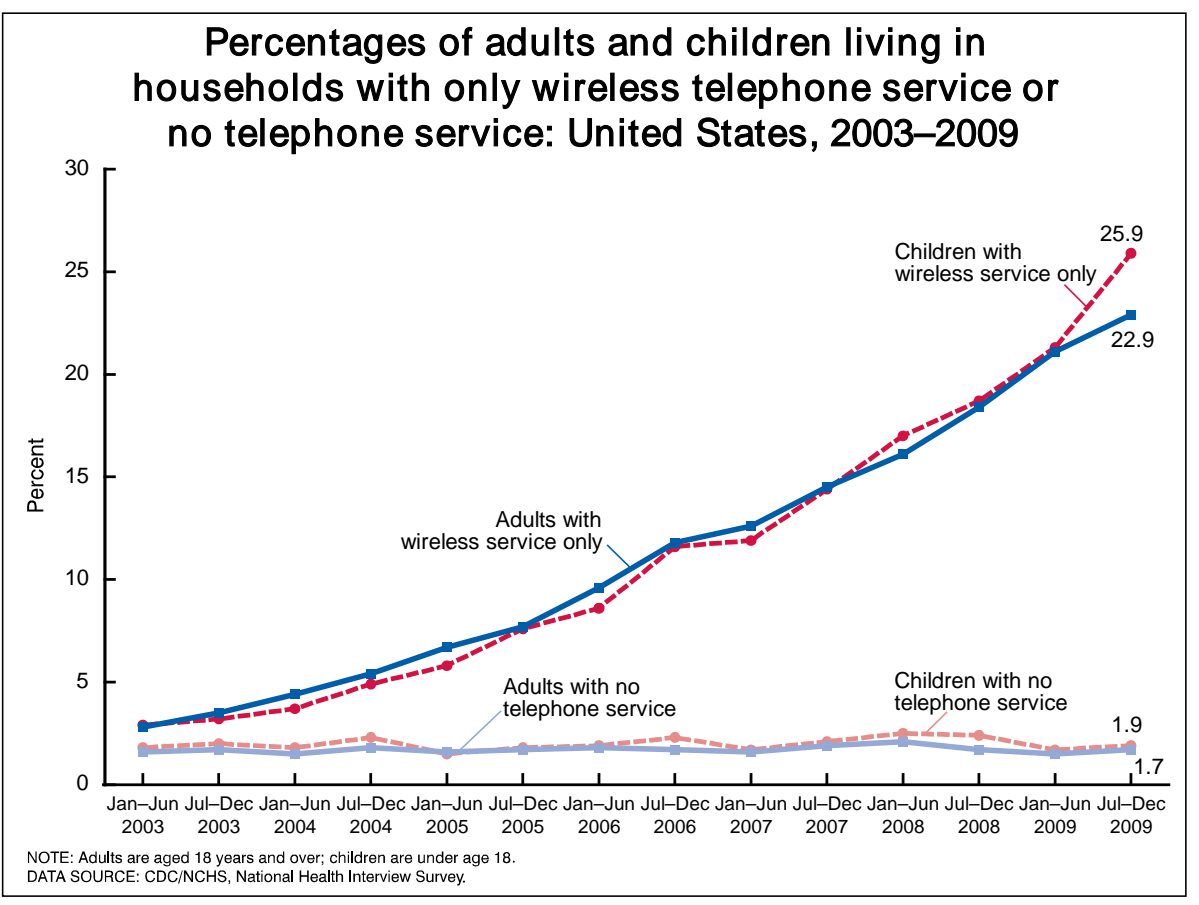

Figure 1 
telephones inside the household.

Persons are identified as wireless-only if they live in a wireless-only household. A similar approach is used to identify adults living in households with no telephone service (neither wireless nor landline). Household telephone status (rather than family telephone status) is used in this report because most telephone surveys draw samples of households rather than families.

From July through December 2009, information on household telephone status was obtained for 21,375 households that included at least one civilian adult or child. These households included 40,619 civilian adults aged 18 years and over and 14,984 children under age 18.

Analyses of demographic characteristics are based on data from the NHIS Person and Household files. Demographic data for all civilian adults living in interviewed households were used in these analyses. Estimates stratified by poverty status are based on reported income only, because imputed income values are not available until a few months after the annual release of NHIS microdata. Household income was unknown for $12 \%$ of adults.

Analyses of selected health measures are based on data from the NHIS Sample Adult file. Health-related data for one civilian adult randomly selected from each family were used in these analyses. From July through December 2009, data on household telephone status and selected health measures were collected from 17,539 randomly selected adults.

Because NHIS is conducted throughout the year and the sample is designed to yield a nationally representative sample each week, data can be analyzed quarterly. Weights are created for each calendar quarter of the NHIS sample. NHIS data weighting procedures are described in more detail in a previous NCHS report (Vital and Health Statistics, series 2, no 130). To provide access to the most recent information from NHIS, estimates using the July-December 2009 data are being released prior to final data editing and final weighting. These estimates should be considered preliminary. If estimates are produced using the final data files, the estimates may differ slightly from those presented here.

Point estimates and 95\% confidence intervals were calculated using SUDAAN software, to account for the complex sample design of NHIS. Differences between percentages were evaluated by using two-sided significance tests at the 0.05 level. Terms such as "more likely" and "less likely” indicate a statistically significant difference. Lack of comment regarding the difference between any two estimates does not necessarily mean that the difference was tested and found to be not significant. Because of small sample sizes, estimates based on less than 1 year of data may have large variances, and caution should be used in interpreting such estimates.

\section{Questionnaire Changes in 2007}

From 2003 to 2006, NHIS families were considered to have landline telephone service if the survey respondent provided a telephone number, identified it as "the family's phone number," and said it was not a cellular telephone number. If the family's phone number was reported to be a cellular telephone number, the respondent was asked if there was "at least one phone inside your home that is currently working and is not a cell phone."

In 2007, the questionnaire was changed so that the survey respondent for each family was asked if there was "at least one phone inside your home that is currently working and is not a cell phone" (unless the respondent had indicated not having any phone when asked for a telephone number).

From 2003 to 2006, the questions about cellular telephones were asked at the end of the survey. Because of incomplete interviews, more than 10\% of households were not asked about wireless telephones. In 2007, the questions were asked earlier in the survey, resulting in fewer families with unknown wireless telephone status.

In 2007, a new question was added to the survey for persons living in families with both landline and cellular telephones. The respondent for the family was asked to consider all of the telephone calls his or her family receives and to report whether "all or almost all calls are received on cell phones, some are received on cell phones and some on regular phones, or very few or none are received on cell phones." This new question permits the identification of persons living in "wireless-mostly" households-defined as households with both landline and cellular telephones in which all families receive all or almost all calls on cell phones.

Finally, in 2007, the questionnaire was redesigned to improve the collection of income information. Initial evaluations suggest that the resulting poverty estimates are generally comparable with those from years 2006 and earlier. However, as a result of the changes, the poverty ratio variable has had fewer missing values since 2007 compared with prior years.

\section{Telephone Status}

In the last 6 months of 2009, one of every four households (24.5\%) did not have a landline telephone but did have at least one wireless telephone (Table 1). Approximately 22.9\% of all adults (approximately 52 million adults) lived in households with only wireless telephones; $25.9 \%$ of all children (more than 19 million children) lived in households with only wireless telephones.

The percentage of households that are wireless-only has been steadily increasing. The 4.3-percentage-point increase from the last 6 months of 2008 through the last 6 months of 2009 is nearly equivalent to the 4.4-percentagepoint increase observed from the last 6 months of 2007 through the last 6 months of 2008 . 
The percentage of adults living in wireless-only households has also been increasing steadily (see Figure 1). During the last 6 months of 2009, more than two of every nine adults lived in wireless-only households. One year before that (i.e., during the last 6 months of 2008), 2 of every 11 adults lived in wireless-only households. And 2 years before that (i.e., during the last 6 months of 2006), only 2 of every 17 adults lived in wireless-only households.

The percentage of children living in wireless-only households is also growing. In fact, for this population, the 4.6-percentage-point increase from the first 6 months of 2009 is the largest 6month increase observed since 2003, when NHIS began collecting data on children living in wireless-only households.

The percentages of adults and children living without any telephone service have remained relatively unchanged over the past 3 years. Approximately 2.0\% of households had no telephone service (neither wireless nor landline). Nearly 4 million adults (1.7\%) and 1.4 million children (1.9\%) lived in these households.

\section{Demographic Differences}

The percentage of U.S. civilian noninstitutionalized adults living in wireless-only households is shown by selected demographic characteristics and by survey time period in Table 2 . For the period July through December 2009,

More than three in five adults living only with unrelated adult roommates (62.9\%) were in households with only wireless telephones. This is the highest prevalence rate among the population subgroups examined.

- More than two in five adults renting their home (43.1\%) had only wireless telephones. Adults renting their home were more likely than adults owning their home (14.0\%) to be living in households with only wireless telephones.

Nearly half of adults aged 25-29 years (48.6\%) lived in households with only wireless telephones. More than one-third of adults aged 18-24 or 30-34 (37.8\% and 37.2\%, respectively) lived in households with only wireless telephones.

As age increased from 35 years, the percentage of adults living in households with only wireless telephones decreased: $23.9 \%$ for adults aged 35-44; $14.9 \%$ for adults aged 45-64; and 5.2\% for adults aged 65 and over. However, as shown in Table 2 and Figure 2, the percentage of wireless-only adults within each age group has increased over time.

Men (24.5\%) were more likely than women (21.3\%) to be living in households with only wireless telephones.

Adults living in poverty (36.3\%) and adults living near poverty (29.0\%) were more likely than higher income adults (19.6\%) to be living in households with only wireless telephones.
Adults living in the Midwest (25.6\%), South (25.4\%), and West (22.2\%) were more likely than adults living in the Northeast (15.1\%) to be living in households with only wireless telephones.

Hispanic adults (30.4\%) were more likely than non-Hispanic white adults (21.0\%) or non-Hispanic black adults (25.0\%) to be living in households with only wireless telephones.

\section{Demographic Distributions}

The demographic differences noted in the previous section are based on the distribution of household telephone status within each demographic group. When examining the population of wireless-only adults, some readers may instead wish to consider the distribution of various demographic characteristics within the wireless-only adult population. For example, although young adults aged 18-29 years were more likely than older adults to live in households with only wireless telephones, these young adults made up only $40.8 \%$ of all wireless-

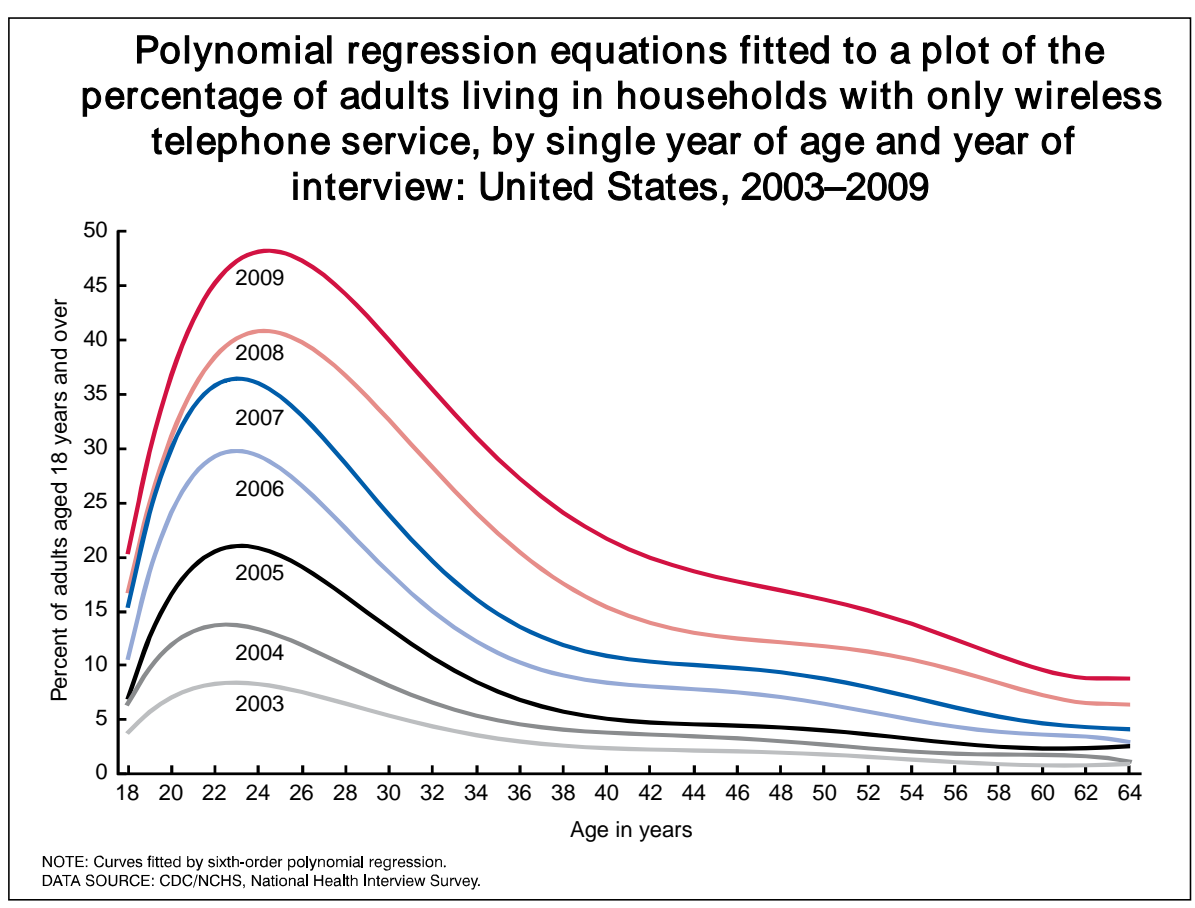

Figure 2 
only adults. Young adults were a minority among all wireless-only adults because young adults made up only $22 \%$ of the total adult population.

Table 3 presents the percent distribution of selected demographic characteristics for adults living in households with only wireless telephones, by survey time period. The estimates in this table reveal that the distributions of selected demographic characteristics changed little over the 4year period shown. The exceptions were related to sex, age, employment status, and household structure. From 2006 to the last 6 months of 2009,

The proportion of women among all wireless-only adults increased from approximately $46 \%$ to $48.2 \%$.

- Among all wireless-only adults, the proportion of adults aged 30 years and over has steadily increased. In the last 6 months of 2009, the majority of wireless-only adults (59.2\%) were aged 30 and over, up from $48.4 \%$ in the first 6 months of 2006.

The proportion of employed adults among all wireless-only adults has decreased from $78.6 \%$ to $69.1 \%$. Over the same time period, the proportion of adults with an employment status other than working, keeping house, or going to school increased. These adults (largely unemployed or retired) made up $20.2 \%$ of wireless-only adults in the last 6 months of 2009, up from $10.3 \%$ in the first 6 months of 2006.

- Among all wireless-only adults, the proportion of adults living with children has steadily increased. In the last 6 months of 2009, 40.0\% of wireless-only adults were living with children, up from $34.6 \%$ in the first 6 months of 2006.

\section{Selected Health Measures by Household Telephone Status}

Many health surveys, political polls, and other research are conducted using random-digit-dial telephone surveys. Until recently, these surveys did not include wireless telephone numbers in their samples. Now, despite operational challenges, most major survey research organizations are including wireless telephone numbers when conducting random-digit-dial telephone surveys. If they did not, the exclusion of households with only wireless telephones (along with the small proportion of households that have no telephone service) could bias results. This bias-known as coverage bias-could exist if there are differences between persons with and without landline telephones for the substantive variables of interest.

The NHIS Early Release Program updates and releases estimates for 15 key health indicators every 3 months. Table 4 presents estimates by household telephone status (landline, wireless-only, or without any telephone service) for all but two of these measures. ("Pneumococcal vaccination" and "personal care needs" were not included because these indicators are limited to older adults aged 65 years and over.) For the period July through December 2009,

The prevalence of binge drinking (i.e., having five or more alcoholic drinks in 1 day during the past year) among wireless-only adults (34.5\%) was nearly twice as high as the prevalence among adults living in landline households (18.7\%). Wireless-only adults were also more likely to be current smokers than were adults living in landline households.

- Compared with adults living in landline households, wireless-only adults were more likely to report that their health status was excellent or very good, more likely to experience serious psychological distress, and less likely to have ever been diagnosed with diabetes.

The percentage without health insurance coverage at the time of interview among wireless-only adults under 65 years of age (29.2\%) was more than twice as high as the percentage among adults in that age group living in landline households (13.8\%).

Compared with adults living in landline households, wireless-only adults were more likely to have experienced financial barriers to obtaining needed health care, and they were less likely to have a usual place to go for medical care. Wireless-only adults were also less likely to have received an influenza vaccination during the previous year.

Wireless-only adults (50.6\%) were more likely than adults living in landline households (36.1\%) to have ever been tested for human immunodeficiency virus (HIV), the virus that causes AIDS.

The potential for bias due to undercoverage remains a real and growing threat to surveys conducted only on landline telephones. Telephone surveys limited to landline households may still be viable for health surveys of all adults and for surveys of most subpopulations regarding their health status (see American Journal of Public Health article by Blumberg and Luke, 2009). However, for health-related behaviors, health care service use indicators, and health care access measures (such as those in Table 4), caution is warranted when using landline surveys to draw inferences about subpopulations more likely to be wireless-only (such as young or lowincome adults).

\section{Wireless-mostly Households}

The potential for bias due to undercoverage is not the only threat to surveys conducted on landline telephones. Researchers are also concerned that some people living in 
households with landlines cannot be reached on those landlines because they rely on wireless telephones for all or almost all of their calls. Among households with both landline and wireless telephones, $25.7 \%$ received all or almost all calls on the wireless telephones, based on data for the period July through December 2009. These wireless-mostly households make up $14.9 \%$ of all households.

The percentage of adults living in wireless-mostly households has been increasing (see Table 5). During the last 6 months of 2009, approximately 37 million adults (16.3\%) lived in wireless-mostly households. This prevalence estimate was not different from the estimate for the first 6 months of 2009 (16.2\%), but it was significantly greater than the estimate for the first 6 months of 2008 (14.4\%).

Table 5 presents the percentage of adults living in wireless-mostly households, by selected demographic characteristics and by survey time period. For the period July through December 2009,

Adults working at a job or business (19.7\%) and adults going to school (21.7\%) were more likely to be living in wireless-mostly households than were adults keeping house (15.1\%) or with another employment status such as retired or unemployed (9.0\%).

- Adults with college degrees (19.7\%) were more likely to be living in wireless-mostly households than were high school graduates (14.2\%) or adults with less education (11.5\%).

- Adults living with children (20.2\%) were more likely than adults living alone $(10.6 \%)$ or with only adult relatives $(15.0 \%)$ to be living in wireless-mostly households.

- Adults living in poverty (10.0\%) and adults living near poverty (12.7\%) were less likely than higher income adults (19.2\%) to be living in wireless-mostly households.

- Adults living in metropolitan areas (16.8\%) were more likely to be living in wireless-mostly households than were adults living in more rural areas (14.5\%).

Recent research by Boyle, Lewis, and Tefft (in the December 2009 issue of Survey Practice) suggests that the majority of adults living in wirelessmostly households are reachable using their landline telephone number. NHIS data cannot be used to estimate the proportion of wireless-only adults who are unreachable or to estimate the potential for bias due to their exclusion from landline surveys.

\section{For More Information}

For more information about the potential implications for health surveys that are based on landline telephone interviews, see

Blumberg SJ, Luke JV. Reevaluating the need for concern regarding noncoverage bias in landline surveys. Am J Public Health 99:1806-10. 2009.

- Blumberg SJ, Luke JV, Cynamon ML, Frankel MR. Recent trends in household telephone coverage in the United States. In: Lepkowski JM et al., eds, Advances in telephone survey methodology. New York: John Wiley and Sons. pp 56-86. 2008.

The potential for bias may differ from one state to another because the prevalence of wireless-only households varies substantially across states. For more information about state-level prevalence estimates from the 2007 NHIS, see

- Blumberg SJ, Luke JV, Davidson G, et al. Wireless substitution: Statelevel estimates from the National Health Interview Survey, JanuaryDecember 2007. National health statistics report; no 14. Hyattsville, MD: National Center for Health Statistics. 2009. Available from: http://www.cdc.gov/nchs/data/nhsr/ nhsr014.pdf.

For more information about NHIS and the NHIS Early Release Program, or to find other Early Release reports, please visit the following websites:

http://www.cdc.gov/nchs/nhis.htm

http://www.cdc.gov/nchs/nhis/ releases.htm.

\section{Suggested Citation}

Blumberg SJ, Luke JV. Wireless substitution: Early release of estimates from the National Health Interview Survey, July-December 2009. National Center for Health Statistics. May 2010. Available from: http://www.cdc.gov/nchs/nhis.htm. 
Table 1. Percent distribution of household telephone status, by date of interview, for households, adults, and children: United States, January 2006-December 2009

\begin{tabular}{|c|c|c|c|c|c|c|c|c|}
\hline \multirow[b]{2}{*}{$\begin{array}{c}\text { Date of } \\
\text { interview }\end{array}$} & & \multicolumn{6}{|c|}{ Household telephone status } & \multirow[b]{2}{*}{ Total } \\
\hline & & $\begin{array}{l}\text { Landline with } \\
\text { a wireless } \\
\text { telephone }\end{array}$ & $\begin{array}{c}\text { Landline without } \\
\text { a wireless } \\
\text { telephone }\end{array}$ & $\begin{array}{l}\text { Landline with } \\
\text { unknown wireless } \\
\text { telephone status }\end{array}$ & $\begin{array}{c}\text { Nonlandline with } \\
\text { unknown wireless } \\
\text { telephone status }\end{array}$ & Wireless-only & $\begin{array}{l}\text { No telephone } \\
\text { service }\end{array}$ & \\
\hline & $\begin{array}{l}\text { Number of } \\
\text { households } \\
\text { (unweighted) }\end{array}$ & \multicolumn{7}{|c|}{ Percent of households } \\
\hline Jan-Jun 2006 & 16,009 & 45.6 & 30.9 & 10.3 & 0.7 & 10.5 & 2.0 & 100.0 \\
\hline Jul-Dec 2006 & 13,056 & 44.3 & 29.6 & 10.2 & 0.8 & 12.8 & 2.2 & 100.0 \\
\hline Jan-Jun $2007^{1}$ & 15,996 & 58.9 & 23.8 & 1.7 & 0.1 & 13.6 & 1.9 & 100.0 \\
\hline Jul-Dec 2007 & 13,083 & 58.8 & 21.8 & 1.3 & 0.1 & 15.8 & 2.2 & 100.0 \\
\hline Jan-Jun 2008 & 16,070 & 58.5 & 20.6 & 0.9 & 0.0 & 17.5 & 2.5 & 100.0 \\
\hline Jul-Dec 2008 & 12,597 & 59.6 & 17.4 & 0.9 & 0.0 & 20.2 & 1.9 & 100.0 \\
\hline Jan-Jun 2009 & 12,447 & 59.4 & 15.5 & 0.4 & 0.0 & 22.7 & 1.9 & 100.0 \\
\hline Jul-Dec 2009 & 21,375 & 58.2 & 14.9 & 0.4 & 0.0 & 24.5 & 2.0 & 100.0 \\
\hline \multicolumn{2}{|c|}{$95 \%$ confidence interval $^{2}$} & 57.14-59.33 & 14.09-15.77 & $0.27-0.47$ & $0.01-0.06$ & $23.60-25.45$ & $1.77-2.19$ & \\
\hline & $\begin{array}{c}\text { Number of } \\
\text { adults } \\
\text { (unweighted) }\end{array}$ & & & Percent o & f adults aged 18 year & Ind over & & \\
\hline Jan-Jun 2006 & 29,842 & 49.5 & 28.2 & 10.4 & 0.6 & 9.6 & 1.8 & 100.0 \\
\hline Jul-Dec 2006 & 24,473 & 48.1 & 27.3 & 10.5 & 0.7 & 11.8 & 1.7 & 100.0 \\
\hline Jan-Jun $2007^{1}$ & 29,982 & 63.3 & 20.8 & 1.7 & 0.1 & 12.6 & 1.6 & 100.0 \\
\hline Jul-Dec 2007 & 24,514 & 63.2 & 19.1 & 1.2 & 0.1 & 14.5 & 1.9 & 100.0 \\
\hline Jan-Jun 2008 & 30,150 & 63.0 & 17.9 & 0.8 & 0.0 & 16.1 & 2.1 & 100.0 \\
\hline Jul-Dec 2008 & 23,726 & 63.7 & 15.1 & 1.0 & 0.0 & 18.4 & 1.7 & 100.0 \\
\hline Jan-Jun 2009 & 23,632 & 63.5 & 13.4 & 0.4 & 0.0 & 21.1 & 1.5 & 100.0 \\
\hline Jul-Dec 2009 & 40,619 & 62.5 & 12.6 & 0.3 & 0.0 & 22.9 & 1.7 & 100.0 \\
\hline \multicolumn{2}{|c|}{$95 \%$ confidence interval $^{2}$} & $61.41-63.60$ & $11.84-13.40$ & $0.25-0.45$ & $0.01-0.04$ & $22.00-23.72$ & $1.50-1.89$ & \\
\hline
\end{tabular}




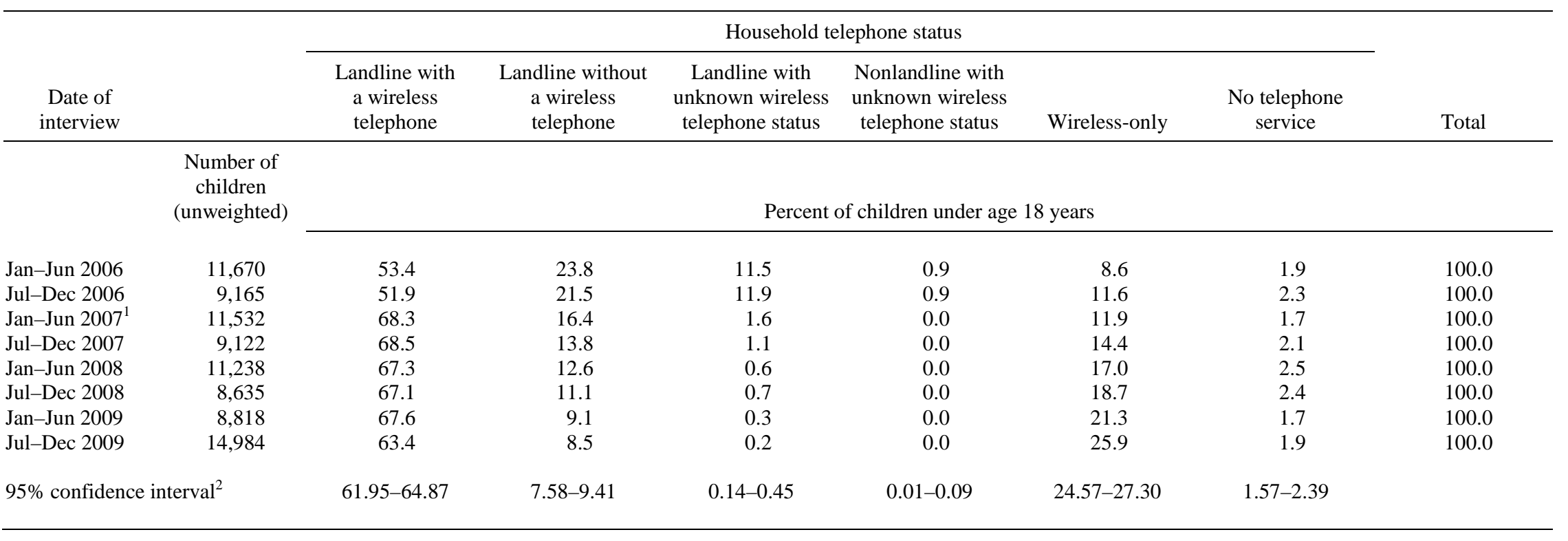

0.0 means quantity is more than zero but less than 0.05 .

${ }^{1}$ Questionnaire changes that occurred in 2007 should be considered when evaluating recent trends in household telephone status. See text for more information about these changes.

${ }^{2}$ Refers to the time period July through December 2009.

DATA SOURCE: National Health Interview Survey, January 2006-December 2009. Data are based on household interviews of a sample of the civilian noninstitutionalized population. 
Table 2. Percentage of adults aged 18 years and over living in wireless-only households, by selected demographic characteristics and by calendar halfyears: United States, January 2006-December 2009

\begin{tabular}{|c|c|c|c|c|c|c|c|c|c|}
\hline \multirow[b]{2}{*}{ Demographic characteristic } & \multicolumn{8}{|c|}{ Calendar half-year } & \multirow[b]{2}{*}{$\begin{array}{l}\text { 95\% confidence } \\
\text { interval }^{2}\end{array}$} \\
\hline & $\begin{array}{l}\text { Jan-Jun } \\
2006\end{array}$ & $\begin{array}{c}\text { Jul-Dec } \\
2006\end{array}$ & $\begin{array}{c}\text { Jan-Jun } \\
2007^{1}\end{array}$ & $\begin{array}{c}\text { Jul-Dec } \\
2007^{1}\end{array}$ & $\begin{array}{c}\text { Jan-Jun } \\
2008\end{array}$ & $\begin{array}{c}\text { Jul-Dec } \\
2008\end{array}$ & $\begin{array}{c}\text { Jan-Jun } \\
2009\end{array}$ & $\begin{array}{c}\text { Jul-Dec } \\
2009\end{array}$ & \\
\hline
\end{tabular}

Race/ethnicity

Hispanic or Latino, any race(s)

Non-Hispanic white, single race

Non-Hispanic black, single race

Non-Hispanic Asian, single race

Non-Hispanic other, single race

Non-Hispanic multiple race

Age

18-24 years

25-29 years

30-34 years

35-44 years

45-64 years

65 years and over

Sex

Male

Female

\section{Education}

Some high school or less

High school graduate or GED ${ }^{3}$

Some post-high school, no degree

4-year college degree or higher

Employment status last week

Working at a job or business

Keeping house

Going to school

Something else (incl. unemployed)

11.2
9.0
10.5
10.2
9.8
15.4


22.6
22.3
12.1
8.2
5.3
1.3

$\begin{array}{ll}15.3 & 18.0 \\ 10.8 & 11.3 \\ 12.8 & 14.3 \\ 11.8 & 10.6 \\ 17.2 & 22.8 \\ 14.6 & 17.3\end{array}$

Percent

See footnotes at end of table.

$\begin{array}{rrrrrr}19.3 & 21.6 & 25.0 & 28.2 & 30.4 & 28.63-32.32 \\ 12.9 & 14.6 & 16.6 & 19.7 & 21.0 & 19.89-22.10 \\ 18.3 & 18.5 & 21.4 & 21.3 & 25.0 & 23.14-27.04 \\ 12.1 & 16.5 & 17.8 & 18.0 & 20.6 & 18.26-23.11 \\ 17.5 & 12.8 & 17.3 & 20.6 & 26.5 & 19.87-34.49 \\ 22.8 & 22.3 & 22.5 & 28.7 & 26.9 & 22.09-32.35 \\ & & & & & \\ 30.6 & 31.4 & 33.1 & 37.6 & 37.8 & 35.38-40.36 \\ 34.5 & 35.7 & 41.5 & 45.8 & 48.6 & 46.48-50.82 \\ 22.0 & 27.0 & 30.4 & 33.5 & 37.2 & 35.05-39.48 \\ 12.5 & 15.5 & 17.5 & 21.5 & 23.9 & 22.51-25.32 \\ 8.0 & 9.2 & 11.6 & 12.8 & 14.9 & 14.07-15.81 \\ 2.2 & 2.8 & 3.3 & 5.4 & 5.2 & 4.55-6.03 \\ & & & & & \\ 15.9 & 18.0 & 20.0 & 22.5 & 24.5 & 23.57-25.43 \\ 13.2 & 14.4 & 17.0 & 19.8 & 21.3 & 20.43-22.24 \\ & & & & & \\ 15.4 & 16.1 & 18.8 & 22.2 & 24.7 & 23.09-26.29 \\ 13.4 & 15.2 & 17.8 & 20.8 & 22.9 & 21.63-24.15 \\ 17.0 & 19.0 & 20.1 & 23.6 & 25.0 & 23.71-26.37 \\ 12.7 & 14.3 & 17.7 & 18.2 & 19.5 & 18.12-20.98 \\ & & & & & \\ 16.6 & 19.0 & 21.5 & 24.3 & 26.0 & 25.03-27.06 \\ 12.8 & 12.6 & 16.0 & 16.6 & 20.5 & 18.78-22.26 \\ 28.9 & 21.5 & 23.5 & 29.7 & 29.2 & 25.21-33.52 \\ 7.6 & 8.9 & 11.0 & 14.0 & 15.9 & 14.87-16.96\end{array}$




\begin{tabular}{|c|c|c|c|c|c|c|c|c|c|}
\hline \multirow[b]{2}{*}{ Demographic characteristic } & \multicolumn{8}{|c|}{ Calendar half-year } & \multirow[b]{2}{*}{$\begin{array}{l}\text { 95\% confidence } \\
\text { interval }^{2}\end{array}$} \\
\hline & $\begin{array}{l}\text { Jan-Jun } \\
2006\end{array}$ & $\begin{array}{l}\text { Jul-Dec } \\
2006\end{array}$ & $\begin{array}{c}\text { Jan-Jun } \\
2007^{1}\end{array}$ & $\begin{array}{l}\text { Jul-Dec } \\
2007^{1}\end{array}$ & $\begin{array}{l}\text { Jan-Jun } \\
2008\end{array}$ & $\begin{array}{l}\text { Jul-Dec } \\
2008\end{array}$ & $\begin{array}{l}\text { Jan-Jun } \\
2009\end{array}$ & $\begin{array}{l}\text { Jul-Dec } \\
2009\end{array}$ & \\
\hline \multicolumn{10}{|l|}{ Household structure } \\
\hline Adult living alone & 16.2 & 18.2 & 20.3 & 22.9 & 24.6 & 28.1 & 30.8 & 32.9 & $31.04-34.79$ \\
\hline Unrelated adults, no children & 44.2 & 54.0 & 55.3 & 56.9 & 63.1 & 60.6 & 68.5 & 62.9 & $54.47-70.62$ \\
\hline Related adults, no children & 7.1 & 8.5 & 9.8 & 11.0 & 12.5 & 14.7 & 16.8 & 17.1 & $16.13-18.20$ \\
\hline Adult(s) with children & 8.6 & 10.5 & 11.3 & 13.0 & 15.1 & 17.2 & 20.4 & 24.1 & $22.92-25.29$ \\
\hline \multicolumn{10}{|l|}{ Household poverty status ${ }^{4}$} \\
\hline Poor & 15.8 & 22.4 & 21.6 & 27.4 & 26.0 & 30.9 & 33.0 & 36.3 & $33.90-38.81$ \\
\hline Near poor & 14.4 & 15.7 & 18.5 & 20.8 & 22.6 & 23.8 & 26.5 & 29.0 & $27.35-30.74$ \\
\hline Not poor & 9.4 & 11.3 & 10.6 & 11.9 & 14.2 & 16.0 & 18.9 & 19.6 & $18.64-20.59$ \\
\hline \multicolumn{10}{|l|}{ Geographic region $^{5}$} \\
\hline Northeast & 7.2 & 8.6 & 8.8 & 10.0 & 9.8 & 11.4 & 14.6 & 15.1 & $13.09-17.27$ \\
\hline Midwest & 10.2 & 11.4 & 14.0 & 15.3 & 17.8 & 20.8 & 21.9 & 25.6 & $23.86-27.51$ \\
\hline South & 11.4 & 14.0 & 14.9 & 17.1 & 19.6 & 21.3 & 25.0 & 25.4 & $24.01-26.93$ \\
\hline West & 7.8 & 11.0 & 10.9 & 12.9 & 13.7 & 17.2 & 19.0 & 22.2 & $20.80-23.76$ \\
\hline \multicolumn{10}{|l|}{ Metropolitan statistical area status } \\
\hline Metropolitan & 10.3 & 12.7 & 13.7 & 15.5 & 17.5 & 19.7 & 22.4 & 24.2 & $23.13-25.20$ \\
\hline Not metropolitan & 7.0 & 8.0 & 8.4 & 10.0 & 10.9 & 13.5 & 16.5 & 17.9 & $16.40-19.54$ \\
\hline \multicolumn{10}{|l|}{ Home ownership status ${ }^{6}$} \\
\hline Owned or being bought & 5.1 & 5.8 & 6.7 & 7.3 & 9.0 & 9.9 & 12.8 & 14.0 & $13.18-14.86$ \\
\hline Renting & 22.5 & 26.4 & 28.2 & 30.9 & 33.6 & 39.2 & 40.9 & 43.1 & $41.51-44.67$ \\
\hline Other arrangement & 10.7 & $* 20.3$ & 22.5 & 23.2 & 23.4 & 17.7 & 33.6 & 33.8 & $27.64-40.52$ \\
\hline $\begin{array}{l}\text { Number of wireless-only adults in } \\
\text { survey sample (unweighted) }\end{array}$ & 2,804 & 2,878 & 3,819 & 3,558 & 4,939 & 4,426 & 5,078 & 9,401 & \\
\hline
\end{tabular}

*Estimate has a relative standard error greater than $30 \%$ and does not meet National Center for Health Statistics (NCHS) standards for reliability or precision.

${ }^{1}$ Questionnaire changes that occurred in 2007 should be considered when evaluating recent trends in household telephone status. See text for more information about these changes.

${ }^{2}$ Refers to the time period July through December 2009.

${ }^{3}$ GED is General Educational Development high school equivalency diploma. 
${ }^{4}$ Based on household income and household size using the U.S. Census Bureau's poverty thresholds. "Poor” persons are defined as those below the poverty threshold. "Near poor" persons have incomes of $100 \%$ to less than $200 \%$ of the poverty threshold. "Not poor" persons have incomes of $200 \%$ of the poverty threshold or greater. Early Release estimates stratified by poverty status are based on reported income only and may differ from similar estimates produced later that are based on both reported and imputed income. NCHS imputes income when income is unknown, but the imputed income file is not available until a few months after the annual release of National Health Interview Survey microdata. For households with multiple families, household income and household size were calculated as the sum of the multiple measures of family income and family size.

${ }^{5}$ In the geographic classification of the U.S. population, states are grouped into the following four regions used by the U.S. Census Bureau. Northeast includes Maine, Vermont, New Hampshire, Massachusetts, Connecticut, Rhode Island, New York, New Jersey, and Pennsylvania. Midwest includes Ohio, Illinois, Indiana, Michigan, Wisconsin, Minnesota, Iowa, Missouri, North Dakota, South Dakota, Kansas, and Nebraska. South includes Delaware, Maryland, District of Columbia, West Virginia, Virginia, Kentucky, Tennessee, North Carolina, South Carolina, Georgia, Florida, Alabama, Mississippi, Louisiana, Oklahoma, Arkansas, and Texas. West includes Washington, Oregon, California, Nevada, New Mexico, Arizona, Idaho, Utah, Colorado, Montana, Wyoming, Alaska, and Hawaii.

${ }^{6}$ For households with multiple families, home ownership status was determined by considering the reported home ownership status for each family. If any family reported owning the home, then the household level variable was classified as "owned or being bought" for all persons living in the household. If one family reported renting the home and another family reported "other arrangement," then the household level variable was classified as "other arrangement” for all persons living in the household.

DATA SOURCE: National Health Interview Survey, January 2006-December 2009. Data are based on household interviews of a sample of the civilian noninstitutionalized population. 
Table 3. Percent distribution of selected demographic characteristics, by date of interview, for adults aged 18 years and over living in wireless-only households: United States, January 2006-December 2009

\begin{tabular}{|c|c|c|c|c|c|c|c|c|c|}
\hline \multirow[b]{2}{*}{ Demographic characteristic } & \multicolumn{8}{|c|}{ Calendar half-year } & \multirow[b]{2}{*}{$\begin{array}{l}\text { 95\% confidence } \\
\text { interval }^{2}\end{array}$} \\
\hline & $\begin{array}{c}\text { Jan-Jun } \\
2006\end{array}$ & $\begin{array}{c}\text { Jul-Dec } \\
2006\end{array}$ & $\begin{array}{c}\text { Jan-Jun } \\
2007^{1}\end{array}$ & $\begin{array}{c}\text { Jul-Dec } \\
2007^{1}\end{array}$ & $\begin{array}{c}\text { Jan-Jun } \\
2008\end{array}$ & $\begin{array}{c}\text { Jul-Dec } \\
2008\end{array}$ & $\begin{array}{c}\text { Jan-Jun } \\
2009\end{array}$ & $\begin{array}{c}\text { Jul-Dec } \\
2009\end{array}$ & \\
\hline \multirow{2}{*}{\multicolumn{10}{|c|}{ Percent distribution }} \\
\hline & & & & & & & & & \\
\hline Hispanic or Latino, any race(s) & 15.2 & 17.1 & 18.9 & 18.0 & 18.1 & 18.5 & 18.4 & 18.5 & $16.86-20.23$ \\
\hline Non-Hispanic white, single race & 65.6 & 64.0 & 61.5 & 61.2 & 62.2 & 61.9 & 63.8 & 62.5 & $60.29-64.63$ \\
\hline Non-Hispanic black, single race & 12.5 & 12.4 & 12.9 & 14.4 & 13.2 & 13.3 & 11.7 & 12.7 & $11.36-14.14$ \\
\hline Non-Hispanic Asian, single race & 4.7 & 4.4 & 3.8 & 3.8 & 4.6 & 4.4 & 3.9 & 4.1 & $3.48-4.88$ \\
\hline Non-Hispanic other, single race & $* 0.6$ & 0.9 & *1.6 & $* 0.8$ & 0.6 & 0.6 & 0.7 & 1.0 & $0.68-1.33$ \\
\hline Non-Hispanic multiple race & 1.4 & 1.2 & 1.3 & 1.8 & 1.3 & 1.2 & 1.5 & 1.3 & $1.00-1.61$ \\
\hline Total & 100.0 & 100.0 & 100.0 & 100.0 & 100.0 & 100.0 & 100.0 & 100.0 & \\
\hline \multicolumn{10}{|l|}{ Age } \\
\hline 18-24 years & 30.5 & 27.6 & 28.4 & 27.2 & 24.9 & 23.1 & 22.9 & 21.2 & $19.72-22.74$ \\
\hline 25-29 years & 21.1 & 22.7 & 22.3 & 22.1 & 20.5 & 21.0 & 19.9 & 19.6 & $18.46-20.69$ \\
\hline 30-34 years & 11.0 & 12.9 & 11.3 & 13.0 & 14.3 & 14.0 & 13.6 & 14.0 & $13.09-15.02$ \\
\hline 35-44 years & 16.8 & 16.6 & 16.3 & 16.3 & 17.8 & 17.4 & 18.4 & 18.6 & $17.53-19.79$ \\
\hline 45-64 years & 18.5 & 17.6 & 19.1 & 18.9 & 19.6 & 21.6 & 21.0 & 22.8 & $21.65-23.91$ \\
\hline 65 years and over & 2.2 & 2.6 & 2.6 & 2.5 & 2.9 & 2.9 & 4.3 & 3.8 & $3.35-4.39$ \\
\hline Total & 100.0 & 100.0 & 100.0 & 100.0 & 100.0 & 100.0 & 100.0 & 100.0 & \\
\hline \multicolumn{10}{|l|}{ Sex } \\
\hline Male & 54.1 & 53.9 & 52.9 & 53.0 & 53.7 & 52.4 & 51.4 & 51.8 & $50.91-52.67$ \\
\hline Female & 45.9 & 46.1 & 47.1 & 47.0 & 46.3 & 47.6 & 48.6 & 48.2 & $47.33-49.09$ \\
\hline Total & 100.0 & 100.0 & 100.0 & 100.0 & 100.0 & 100.0 & 100.0 & 100.0 & \\
\hline \multicolumn{10}{|l|}{ Education } \\
\hline Some high school or less & 14.8 & 17.4 & 17.5 & 16.2 & 15.5 & 15.8 & 15.5 & 16.0 & $14.76-17.23$ \\
\hline High school graduate or GED ${ }^{3}$ & 28.3 & 27.0 & 27.5 & 27.5 & 27.8 & 27.2 & 27.7 & 28.9 & $27.49-30.36$ \\
\hline Some post-high school, no degree & 34.7 & 34.2 & 32.7 & 32.9 & 33.9 & 31.7 & 33.3 & 32.9 & $31.49-34.31$ \\
\hline 4-year college degree or higher & 22.1 & 21.4 & 22.3 & 23.4 & 22.8 & 25.3 & 23.5 & 22.3 & $20.95-23.62$ \\
\hline Total & 100.0 & 100.0 & 100.0 & 100.0 & 100.0 & 100.0 & 100.0 & 100.0 & \\
\hline
\end{tabular}

See footnotes at end of table. 


\begin{tabular}{|c|c|c|c|c|c|c|c|c|c|}
\hline \multirow[b]{2}{*}{ Demographic characteristic } & \multicolumn{8}{|c|}{ Calendar half-year } & \multirow[b]{2}{*}{$\begin{array}{l}\text { 95\% confidence } \\
\text { interval }^{2}\end{array}$} \\
\hline & $\begin{array}{l}\text { Jan-Jun } \\
2006\end{array}$ & $\begin{array}{c}\text { Jul-Dec } \\
2006\end{array}$ & $\begin{array}{l}\text { Jan-Jun } \\
2007^{1}\end{array}$ & $\begin{array}{l}\text { Jul-Dec } \\
2007^{1}\end{array}$ & $\begin{array}{c}\text { Jan-Jun } \\
2008\end{array}$ & $\begin{array}{l}\text { Jul-Dec } \\
2008\end{array}$ & $\begin{array}{c}\text { Jan-Jun } \\
2009\end{array}$ & $\begin{array}{c}\text { Jul-Dec } \\
2009\end{array}$ & \\
\hline \multicolumn{10}{|l|}{ Employment status last week } \\
\hline Working at a job or business & 78.6 & 76.7 & 77.1 & 74.3 & 75.9 & 74.5 & 71.1 & 69.1 & $67.73-70.36$ \\
\hline Keeping house & 5.2 & 4.9 & 5.2 & 5.6 & 5.0 & 5.3 & 4.5 & 5.3 & $4.82-5.79$ \\
\hline Going to school & 5.6 & 4.9 & 5.1 & 5.8 & 4.1 & 3.7 & 4.6 & 4.4 & $3.68-5.20$ \\
\hline Something else (incl. unemployed) & 10.3 & 13.0 & 12.1 & 13.1 & 13.7 & 15.4 & 18.7 & 20.2 & $19.07-21.43$ \\
\hline Unknown, not reported & $* 0.2$ & 0.6 & 0.6 & $* 1.3$ & 1.4 & $* 1.1$ & 1.1 & 1.1 & $0.78-1.42$ \\
\hline Total & 100.0 & 100.0 & 100.0 & 100.0 & 100.0 & 100.0 & 100.0 & 100.0 & \\
\hline \multicolumn{10}{|l|}{ Household structure } \\
\hline Adult living alone & 25.4 & 24.2 & 25.1 & 24.4 & 23.2 & 23.6 & 22.1 & 21.9 & $20.69-23.25$ \\
\hline Unrelated adults, no children & 6.8 & 10.1 & 6.0 & 7.7 & 6.4 & 5.2 & 5.4 & 4.1 & $3.20-5.11$ \\
\hline Related adults, no children & 33.1 & 32.4 & 34.4 & 34.2 & 35.1 & 36.9 & 36.0 & 34.0 & $32.35-35.60$ \\
\hline Adult(s) with children & 34.6 & 33.3 & 34.6 & 33.7 & 35.3 & 34.3 & 36.4 & 40.0 & $38.33-41.78$ \\
\hline Total & 100.0 & 100.0 & 100.0 & 100.0 & 100.0 & 100.0 & 100.0 & 100.0 & \\
\hline \multicolumn{10}{|l|}{ Household poverty status ${ }^{4}$} \\
\hline Poor & 12.7 & 15.7 & 14.6 & 16.1 & 14.1 & 15.5 & 15.5 & 16.4 & $15.01-17.79$ \\
\hline Near poor & 19.5 & 17.1 & 18.4 & 18.4 & 18.1 & 16.8 & 17.9 & 18.5 & $17.26-19.72$ \\
\hline Not poor & 47.9 & 46.2 & 50.5 & 49.7 & 53.4 & 53.3 & 56.7 & 53.0 & $51.04-54.88$ \\
\hline Unknown, not reported & 19.9 & 21.0 & 16.5 & 15.8 & 14.4 & 14.4 & 10.0 & 12.2 & $11.11-13.44$ \\
\hline Total & 100.0 & 100.0 & 100.0 & 100.0 & 100.0 & 100.0 & 100.0 & 100.0 & \\
\hline \multicolumn{10}{|l|}{ Geographic region $^{5}$} \\
\hline Northeast & 13.8 & 13.4 & 12.7 & 12.4 & 10.7 & 11.3 & 12.2 & 12.1 & $10.41-13.93$ \\
\hline Midwest & 24.1 & 22.2 & 25.1 & 24.6 & 25.0 & 26.0 & 23.9 & 26.0 & $23.90-28.32$ \\
\hline South & 44.1 & 44.4 & 42.6 & 42.7 & 45.2 & 41.1 & 43.8 & 39.5 & $37.16-41.82$ \\
\hline West & 18.0 & 20.0 & 19.7 & 20.4 & 19.1 & 21.6 & 20.1 & 22.4 & $20.55-24.43$ \\
\hline Total & 100.0 & 100.0 & 100.0 & 100.0 & 100.0 & 100.0 & 100.0 & 100.0 & \\
\hline \multicolumn{10}{|l|}{ Metropolitan statistical area status } \\
\hline Metropolitan & 84.4 & 86.7 & 86.1 & 86.9 & 85.9 & 85.1 & 83.3 & 83.7 & $81.68-85.48$ \\
\hline Not metropolitan & 15.6 & 13.3 & 13.9 & 13.1 & 14.1 & 14.9 & 16.7 & 16.3 & $14.52-18.32$ \\
\hline Total & 100.0 & 100.0 & 100.0 & 100.0 & 100.0 & 100.0 & 100.0 & 100.0 & \\
\hline
\end{tabular}

See footnotes at end of table. 


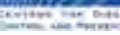

\begin{tabular}{|c|c|c|c|c|c|c|c|c|c|}
\hline \multirow[b]{2}{*}{ Demographic characteristic } & \multicolumn{8}{|c|}{ Calendar half-year } & \multirow[b]{2}{*}{$\begin{array}{l}\text { 95\% confidence } \\
\text { interval }^{2}\end{array}$} \\
\hline & $\begin{array}{l}\text { Jan-Jun } \\
2006\end{array}$ & $\begin{array}{l}\text { Jul-Dec } \\
2006\end{array}$ & $\begin{array}{l}\text { Jan-Jun } \\
2007^{1}\end{array}$ & $\begin{array}{l}\text { Jul-Dec } \\
2007^{1}\end{array}$ & $\begin{array}{l}\text { Jan-Jun } \\
2008\end{array}$ & $\begin{array}{l}\text { Jul-Dec } \\
2008\end{array}$ & $\begin{array}{c}\text { Jan-Jun } \\
2009\end{array}$ & $\begin{array}{l}\text { Jul-Dec } \\
2009\end{array}$ & \\
\hline \multicolumn{10}{|l|}{ Home ownership status ${ }^{6}$} \\
\hline Owned or being bought & 37.4 & 33.8 & 37.7 & 34.8 & 39.2 & 37.1 & 42.1 & 42.3 & $40.24-44.47$ \\
\hline Renting & 60.5 & 62.6 & 59.0 & 61.3 & 58.1 & 61.1 & 55.0 & 54.3 & $52.18-56.48$ \\
\hline Other arrangement & 2.1 & $* 3.7$ & 3.3 & 3.8 & 2.7 & 1.8 & 2.9 & 3.3 & $2.59-4.24$ \\
\hline Total & 100.0 & 100.0 & 100.0 & 100.0 & 100.0 & 100.0 & 100.0 & 100.0 & \\
\hline $\begin{array}{l}\text { Number of wireless-only adults in } \\
\text { survey sample (unweighted) }\end{array}$ & 2,804 & 2,878 & 3,819 & 3,558 & 4,939 & 4,426 & 5,078 & 9,401 & \\
\hline
\end{tabular}

*Estimate has a relative standard error greater than $30 \%$ and does not meet National Center for Health Statistics (NCHS) standards for reliability or precision.

${ }^{1}$ Questionnaire changes that occurred in 2007 should be considered when evaluating recent trends in household telephone status. See text for more information about these changes.

${ }^{2}$ Refers to the time period July through December 2009.

${ }^{3}$ GED is General Educational Development high school equivalency diploma.

${ }^{4}$ Based on household income and household size using the U.S. Census Bureau's poverty thresholds. "Poor” persons are defined as those below the poverty threshold. "Near poor" persons have incomes of $100 \%$ to less than $200 \%$ of the poverty threshold. "Not poor" persons have incomes of $200 \%$ of the poverty threshold or greater. Early Release estimates stratified by poverty status are based on reported income only and may differ from similar estimates produced later that are based on both reported and imputed income. NCHS imputes income when income is unknown, but the imputed income file is not available until a few months after the annual release of National Health Interview Survey microdata. For households with multiple families, household income and household size were calculated as the sum of the multiple measures of family income and family size.

${ }^{5}$ In the geographic classification of the U.S. population, states are grouped into the following four regions used by the U.S. Census Bureau. Northeast includes Maine, Vermont, New Hampshire, Massachusetts, Connecticut, Rhode Island, New York, New Jersey, and Pennsylvania. Midwest includes Ohio, Illinois, Indiana, Michigan, Wisconsin, Minnesota, Iowa, Missouri, North Dakota, South Dakota, Kansas, and Nebraska. South includes Delaware, Maryland, District of Columbia, West Virginia, Virginia, Kentucky, Tennessee, North Carolina, South Carolina, Georgia, Florida, Alabama, Mississippi, Louisiana, Oklahoma, Arkansas, and Texas. West includes Washington, Oregon, California, Nevada, New Mexico, Arizona, Idaho, Utah, Colorado, Montana, Wyoming, Alaska, and Hawaii.

${ }^{6}$ For households with multiple families, home ownership status was determined by considering the reported home ownership status for each family. If any family reported owning the home, then the household level variable was classified as "owned or being bought" for all persons living in the household. If one family reported renting the home and another family reported "other arrangement," then the household level variable was classified as "other arrangement" for all persons living in the household.

DATA SOURCE: National Health Interview Survey, January 2006-December 2009. Data are based on household interviews of a sample of the civilian noninstitutionalized population. 
Table 4. Prevalence rates (and 95\% confidence intervals) for selected measures of health-related behaviors, health status, health care service use, and health care access for adults aged 18 years and over, by household telephone status: United States, July-December 2009

\begin{tabular}{|c|c|c|c|c|c|c|}
\hline \multirow[b]{2}{*}{ Measure } & \multicolumn{6}{|c|}{ Household telephone status } \\
\hline & \multicolumn{2}{|r|}{ Landline $^{1}$} & \multicolumn{2}{|c|}{ Wireless-only } & \multicolumn{2}{|c|}{ No telephone service } \\
\hline & \multicolumn{6}{|c|}{ Percent (95\% confidence interval) } \\
\hline \multicolumn{7}{|l|}{ Health-related behaviors } \\
\hline $\begin{array}{l}\text { Five or more alcoholic drinks in } 1 \text { day at } \\
\text { least once in past year }{ }^{2}\end{array}$ & 18.7 & $(17.75-19.74)$ & 34.5 & $(32.49-36.58)$ & 24.2 & $(19.99-29.09)$ \\
\hline Current smoker $^{\frac{1}{3}}$ & 18.3 & $(17.38-19.24)$ & 27.3 & $(25.53-29.10)$ & 33.2 & $(27.29-39.65)$ \\
\hline $\begin{array}{l}\text { Engaged in regular leisure-time physical } \\
\text { activity }^{4}\end{array}$ & 32.8 & $(31.49-34.06)$ & 39.6 & $(37.65-41.49)$ & 25.0 & $(20.07-30.75)$ \\
\hline \multicolumn{7}{|l|}{ Health status } \\
\hline $\begin{array}{l}\text { Health status described as excellent or very } \\
\text { good }^{5}\end{array}$ & 59.3 & $(58.16-60.34)$ & 65.0 & $(63.11-66.89)$ & 49.6 & $(43.32-55.91)$ \\
\hline $\begin{array}{l}\text { Experienced serious psychological distress } \\
\text { in past } 30 \text { days }^{6}\end{array}$ & 2.7 & $(2.41-3.10)$ & 4.6 & $(3.91-5.38)$ & 6.1 & $(3.69-9.94)$ \\
\hline Obese $^{7}$ (adults aged 20 years and over) & 28.9 & $(27.93-29.84)$ & 26.4 & $(24.80-28.03)$ & 31.5 & $(26.06-37.42)$ \\
\hline Asthma episode in past year ${ }^{8}$ & 3.6 & $(3.30-4.03)$ & 4.5 & $(3.80-5.26)$ & 4.1 & $(2.31-7.15)$ \\
\hline Ever diagnosed with diabetes ${ }^{9}$ & 9.8 & $(9.27-10.46)$ & 5.5 & $(4.80-6.25)$ & 4.7 & $(3.04-7.27)$ \\
\hline \multicolumn{7}{|l|}{ Health care service use } \\
\hline $\begin{array}{l}\text { Received influenza vaccine during past } \\
\text { year }{ }^{10}\end{array}$ & 38.2 & $(37.08-39.35)$ & 23.2 & $(21.77-24.59)$ & 20.3 & $(15.77-25.63)$ \\
\hline Ever been tested for HIV ${ }^{11}$ & 36.1 & $(34.86-37.40)$ & 50.6 & $(48.78-52.49)$ & 44.4 & $(37.80-51.28)$ \\
\hline \multicolumn{7}{|l|}{ Health care access } \\
\hline Has a usual place to go for medical care ${ }^{12}$ & 86.5 & $(85.57-87.35)$ & 72.5 & $(70.71-74.18)$ & 69.1 & $(62.96-74.56)$ \\
\hline $\begin{array}{l}\text { Failed to obtain needed medical care in } \\
\text { past year due to financial barriers }{ }^{13}\end{array}$ & 7.2 & $(6.71-7.81)$ & 13.7 & $(12.45-15.06)$ & 15.8 & $(12.22-20.29)$ \\
\hline $\begin{array}{l}\text { Currently uninsured (adults aged 18-64 } \\
\text { years) }\end{array}$ & 13.8 & $(12.98-14.72)$ & 29.2 & $(27.29-31.14)$ & 34.4 & $(28.70-40.66)$ \\
\hline $\begin{array}{l}\text { Number of adults in survey sample } \\
\text { (unweighted) }\end{array}$ & & 12,505 & & 4,645 & & 389 \\
\hline
\end{tabular}

\footnotetext{
${ }^{1}$ Includes households that also have wireless telephone service.

${ }^{2}$ Defined as the 12 months prior to interview. The analyses excluded adults with unknown alcohol consumption (about $2 \%$ of respondents each year).

${ }^{3}$ Defined as a person who had smoked more than 100 cigarettes in his or her lifetime and now smokes every day or some days. The analyses excluded persons with unknown smoking status (about $2 \%$ of respondents each year).

${ }^{4}$ Defined as engaging in light-moderate leisure-time physical activity for greater than or equal to 30 minutes at a frequency greater than or equal to five times per week or engaging in vigorous leisure-time physical activity for greater than or equal to 20 minutes at a frequency greater than or equal to three times per week. Persons who were known to have not met the frequency recommendations are classified as "not regular," regardless of duration. The analyses excluded persons with unknown physical activity participation (about 3\% of respondents each year).

${ }^{5}$ Data were obtained by asking respondents to assess their own health and that of family members living in the same household as excellent, very good, good, fair, or poor. The analyses excluded persons with unknown health status (about $0.2 \%$ of respondents each year).

${ }^{6}$ Six psychological distress questions are included in the National Health Interview Survey. These questions ask how often during the past 30 days a respondent experienced certain symptoms of psychological distress (feeling so sad that nothing could cheer you up, nervous, restless or fidgety, hopeless, worthless, that everything was an effort). The response codes (0-4) of the six items for each person were equally weighted and summed. A value of 13 or more for this scale indicates that at least one symptom was experienced "most of the time" or "all of the time" and is used here to define serious psychological distress.
} 
${ }^{7}$ Defined as a body mass index (BMI) of $30 \mathrm{~kg} / \mathrm{m}^{2}$ or more. The measure is based on self-reported height and weight. The analyses excluded people with unknown height or weight (about $6 \%$ of respondents each year). Estimates of obesity are presented for adults aged 20 years and over because the Healthy People 2010 objectives (http://www.healthypeople.gov) for healthy weight among adults define adults as persons aged 20 and over.

${ }^{8}$ Information on an episode of asthma or an asthma attack during the past year is self-reported by adults aged 18 years and over. A year is defined as the 12 months prior to interview. The analyses excluded people with unknown asthma episode status (about $0.1 \%$ of respondents each year).

${ }^{9}$ Prevalence of diagnosed diabetes is based on self-report of ever having been diagnosed with diabetes by a doctor or other health professional. Persons reporting "borderline" diabetes status and women reporting diabetes only during pregnancy were not coded as having diabetes in the analyses. The analyses excluded persons with unknown diabetes status (about $0.1 \%$ of respondents each year).

${ }^{10}$ Receipt of flu shots and receipt of nasal spray flu vaccinations were included in the calculation of flu vaccination estimates. Estimates are subject to recall error, which will vary depending on when the question is asked because the receipt of a flu vaccination is seasonal. The analyses excluded those with unknown flu vaccination status (about 3\% of respondents each year).

${ }^{11}$ Individuals who received human immunodeficiency virus (HIV) testing solely as a result of blood donation were considered not to have been tested for HIV. The analyses excluded those with unknown HIV test status (about $5 \%$ of respondents each year).

${ }^{12}$ The usual place to go for medical care does not include a hospital emergency room. The analyses excluded persons with an unknown usual place to go for medical care (about $1.5 \%$ of respondents each year).

${ }^{13} \mathrm{~A}$ year is defined as the 12 months prior to interview. The analyses excluded persons with unknown responses to the question on failure to obtain needed medical care due to cost (about $0.2 \%$ of respondents each year).

${ }^{14}$ A person was defined as uninsured if he or she did not have any private health insurance, Medicare, Medicaid, Children’s Health Insurance Program (CHIP), state-sponsored or other government-sponsored health plan, or military plan at the time of the interview. A person was also defined as uninsured if he or she had only Indian Health Service coverage or had only a private plan that paid for one type of service, such as accidents or dental care. The data on health insurance status were edited using an automated system based on logic checks and keyword searches. The analyses excluded persons with unknown health insurance status (about $1 \%$ of respondents each year).

DATA SOURCE: National Health Interview Survey, July-December 2009. Data are based on household interviews of a sample of the civilian noninstitutionalized population. 
Table 5. Percentage of adults aged 18 years and over living in wireless-mostly households, by selected demographic characteristics and by calendar half-years: United States, January 2007-December 2009

\begin{tabular}{|c|c|c|c|c|c|c|c|}
\hline \multirow[b]{2}{*}{ Demographic characteristic } & \multicolumn{6}{|c|}{ Calendar half-year } & \multirow[b]{2}{*}{$\begin{array}{l}\text { 95\% confidence } \\
\text { interval }^{1}\end{array}$} \\
\hline & $\begin{array}{l}\text { Jan-Jun } \\
2007\end{array}$ & $\begin{array}{c}\text { Jul-Dec } \\
2007\end{array}$ & $\begin{array}{l}\text { Jan-Jun } \\
2008\end{array}$ & $\begin{array}{c}\text { Jul-Dec } \\
2008\end{array}$ & $\begin{array}{c}\text { Jan-Jun } \\
2009\end{array}$ & $\begin{array}{c}\text { Jul-Dec } \\
2009\end{array}$ & \\
\hline & \multicolumn{6}{|c|}{ Percent $^{2}$} & \\
\hline Total & 12.6 & 14.0 & 14.4 & 15.4 & 16.2 & 16.3 & $15.69-17.03$ \\
\hline \multicolumn{8}{|l|}{ Race/ethnicity } \\
\hline Hispanic or Latino, any race(s) & 13.2 & 14.5 & 16.0 & 15.9 & 18.0 & 16.9 & $15.50-18.36$ \\
\hline Non-Hispanic white, single race & 12.3 & 13.2 & 14.2 & 14.9 & 15.6 & 16.1 & $15.24-16.99$ \\
\hline Non-Hispanic black, single race & 11.9 & 15.1 & 13.3 & 14.7 & 15.0 & 16.2 & $14.65-17.89$ \\
\hline Non-Hispanic Asian, single race & 16.0 & 20.3 & 16.4 & 20.3 & 19.6 & 18.5 & $16.20-20.98$ \\
\hline Non-Hispanic other single race & 14.6 & $* 8.6$ & $* 10.1$ & 15.5 & 22.9 & *16.1 & $8.28-28.82$ \\
\hline Non-Hispanic multiple race & 14.6 & 19.7 & 17.7 & 24.2 & 22.5 & 18.2 & $13.80-23.67$ \\
\hline \multicolumn{8}{|l|}{ Age } \\
\hline 18-24 years & 17.3 & 18.2 & 19.2 & 18.8 & 20.0 & 19.9 & $18.23-21.71$ \\
\hline 25-29 years & 17.2 & 19.7 & 17.3 & 18.3 & 17.7 & 16.4 & $14.97-17.99$ \\
\hline 30-44 years & 15.5 & 17.3 & 18.2 & 19.0 & 20.3 & 19.5 & $18.46-20.54$ \\
\hline 45-64 years & 11.5 & 13.0 & 13.8 & 15.4 & 16.5 & 17.5 & $16.56-18.44$ \\
\hline 65 years and over & 3.4 & 3.9 & 4.4 & 4.9 & 5.3 & 6.3 & $5.55-7.09$ \\
\hline \multicolumn{8}{|l|}{ Sex } \\
\hline Male & 13.2 & 14.3 & 14.9 & 15.4 & 16.2 & 16.5 & $15.78-17.28$ \\
\hline Female & 12.0 & 13.6 & 14.0 & 15.2 & 16.1 & 16.2 & $15.50-16.91$ \\
\hline \multicolumn{8}{|l|}{ Education } \\
\hline Some high school or less & 8.0 & 8.7 & 10.0 & 9.8 & 12.1 & 11.5 & $10.40-12.73$ \\
\hline High school graduate or GED ${ }^{3}$ & 10.6 & 12.7 & 12.5 & 13.2 & 13.7 & 14.2 & $13.23-15.25$ \\
\hline Some post-high school, no degree & 15.7 & 16.6 & 17.0 & 18.6 & 17.7 & 18.1 & $16.99-19.19$ \\
\hline 4-year college degree or higher & 14.9 & 16.2 & 17.1 & 18.0 & 19.7 & 19.7 & $18.67-20.78$ \\
\hline \multicolumn{8}{|l|}{ Employment status last week } \\
\hline Working at a job or business & 15.5 & 16.8 & 17.3 & 18.4 & 19.5 & 19.7 & $18.92-20.59$ \\
\hline Keeping house & 9.3 & 10.4 & 11.9 & 11.9 & 12.7 & 15.1 & $13.50-16.90$ \\
\hline Going to school & 17.2 & 20.4 & 25.2 & 21.5 & 21.1 & 21.7 & $18.72-24.95$ \\
\hline Something else (incl. unemployed) & 5.3 & 6.7 & 6.6 & 7.8 & 9.0 & 9.0 & $8.29-9.74$ \\
\hline \multicolumn{8}{|l|}{ Household structure } \\
\hline Adult living alone & 10.8 & 10.7 & 10.1 & 12.2 & 10.0 & 10.6 & $9.67-11.65$ \\
\hline Unrelated adults, no children & 13.9 & 20.1 & $* 15.4$ & 21.3 & 13.9 & 15.5 & $10.02-23.10$ \\
\hline Related adults, no children & 11.6 & 12.1 & 12.8 & 13.2 & 14.7 & 15.0 & $14.00-16.11$ \\
\hline Adult(s) with children & 14.4 & 17.2 & 18.1 & 19.2 & 20.5 & 20.2 & $19.05-21.47$ \\
\hline \multicolumn{8}{|l|}{ Household poverty status ${ }^{4}$} \\
\hline Poor & 8.4 & 8.6 & 10.8 & 9.5 & 11.0 & 10.0 & $8.51-11.76$ \\
\hline Near poor & 9.7 & 11.4 & 10.3 & 11.3 & 12.0 & 12.7 & $11.36-14.11$ \\
\hline Not poor & 14.8 & 15.9 & 17.1 & 18.2 & 18.8 & 19.2 & $18.31-20.14$ \\
\hline \multicolumn{8}{|l|}{ Geographic region $^{5}$} \\
\hline Northeast & 11.3 & 11.7 & 13.8 & 12.0 & 15.3 & 14.9 & $13.41-16.56$ \\
\hline Midwest & 10.6 & 13.3 & 12.6 & 13.2 & 14.6 & 14.7 & $13.35-16.20$ \\
\hline South & 13.8 & 14.3 & 14.6 & 16.2 & 16.7 & 17.3 & $16.15-18.48$ \\
\hline West & 13.7 & 15.9 & 16.4 & 18.7 & 17.7 & 17.7 & $16.40-19.05$ \\
\hline \multicolumn{8}{|l|}{ Metropolitan statistical area status } \\
\hline Metropolitan & 13.2 & 14.7 & 15.0 & 15.8 & 16.9 & 16.8 & $16.14-17.57$ \\
\hline Not metropolitan & 10.2 & 10.9 & 12.1 & 13.4 & 13.5 & 14.5 & $12.97-16.11$ \\
\hline
\end{tabular}

See footnotes at end of table. 


\begin{tabular}{|c|c|c|c|c|c|c|c|}
\hline \multirow[b]{2}{*}{ Demographic characteristic } & \multicolumn{6}{|c|}{ Calendar half-year } & \multirow[b]{2}{*}{$\begin{array}{c}95 \% \text { confidence }^{\text {interval }}{ }^{1} \\
\end{array}$} \\
\hline & $\begin{array}{c}\text { Jan-Jun } \\
2007\end{array}$ & $\begin{array}{c}\text { Jul-Dec } \\
2007\end{array}$ & $\begin{array}{c}\text { Jan-Jun } \\
2008\end{array}$ & $\begin{array}{c}\text { Jul-Dec } \\
2008\end{array}$ & $\begin{array}{c}\text { Jan-Jun } \\
2009\end{array}$ & $\begin{array}{c}\text { Jul-Dec } \\
2009\end{array}$ & \\
\hline \multicolumn{8}{|l|}{ Home ownership status ${ }^{6}$} \\
\hline Owned or being bought & 12.1 & 14.0 & 14.7 & 15.9 & 17.2 & 17.5 & $16.63-18.46$ \\
\hline Renting & 13.9 & 13.8 & 13.9 & 13.0 & 13.9 & 13.6 & $12.63-14.70$ \\
\hline Other arrangement & 12.2 & 14.1 & 14.8 & 24.6 & 13.8 & 15.8 & $11.47-21.40$ \\
\hline $\begin{array}{l}\text { Number of adults in survey sample } \\
\text { who live in landline households } \\
\text { with wireless telephones } \\
\text { (unweighted) }\end{array}$ & 18,631 & 15,356 & 18,664 & 14,816 & 14,886 & 24,904 & \\
\hline
\end{tabular}

* Estimate has a relative standard error greater than 30\% and does not meet National Center for Health Statistics (NCHS) standards for reliability.

${ }^{1}$ Refers to the estimate of the percentage of adults living in wireless-mostly households for the time period July through December 2009.

${ }^{2}$ The sum of the percentage of adults in households that receive all or nearly all calls on wireless phones (shown here) and the percentage of adults in households that receive some or very few calls on wireless phones (data not shown) is equal to the percentage of adults living in landline households with wireless telephones (see Table 1).

${ }^{3}$ GED is General Educational Development high school equivalency diploma.

${ }^{4}$ Based on household income and household size using the U.S. Census Bureau's poverty thresholds. "Poor” persons are defined as those below the poverty threshold. "Near poor" persons have incomes of $100 \%$ to less than $200 \%$ of the poverty threshold.

"Not poor" persons have incomes of $200 \%$ of the poverty threshold or greater. Early Release estimates stratified by poverty status are based on reported income only and may differ from similar estimates produced later that are based on both reported and imputed income. NCHS imputes income when income is unknown, but the imputed income file is not available until a few months after the annual release of National Health Interview Survey microdata. For households with multiple families, household income and household size were calculated as the sum of the multiple measures of family income and family size.

${ }^{5}$ In the geographic classification of the U.S. population, states are grouped into the following four regions used by the U.S. Census Bureau. Northeast includes Maine, Vermont, New Hampshire, Massachusetts, Connecticut, Rhode Island, New York, New Jersey, and Pennsylvania. Midwest includes Ohio, Illinois, Indiana, Michigan, Wisconsin, Minnesota, Iowa, Missouri, North Dakota, South Dakota, Kansas, and Nebraska. South includes Delaware, Maryland, District of Columbia, West Virginia, Virginia, Kentucky, Tennessee, North Carolina, South Carolina, Georgia, Florida, Alabama, Mississippi, Louisiana, Oklahoma, Arkansas, and Texas. West includes Washington, Oregon, California, Nevada, New Mexico, Arizona, Idaho, Utah, Colorado, Montana, Wyoming, Alaska, and Hawaii.

${ }^{6}$ For households with multiple families, home ownership status was determined by considering the reported home ownership status for each family. If any family reported owning the home, then the household level variable was classified as "owned or being bought" for all persons living in the household. If one family reported renting the home and another family reported "other arrangement," then the household level variable was classified as "other arrangement” for all persons living in the household.

DATA SOURCE: National Health Interview Survey, January 2007-December 2009. Data are based on household interviews of a sample of the civilian noninstitutionalized population. 